Multi Colors: An International Journal of

Educational Research and Theory Vol 1(1), 2018-19

\title{
Fin-de-Siècle Rural Teachers in the French Third Republic and in Hebrew Galilee Moshavot
}

\author{
Yair Seltenreich (emeritus), Tel-Hai Academic College \\ Correspondence concerning this article should be addressed to Yair Seltenreich \\ yairs@telhai.ac.il
}

\begin{abstract}
In 1882moderneducationinboth Franceand the Galileebeganamassiveand continuous penetration into rural zones, followed by deep tensions between modernist teachers and local conservative populations. Many similarities existed between those two seemingly unconnected rural environments. This article analyzes the essence and the significances of similar features of the above processes and considers whether they might be the result of transnational influences. In both arenas, tensions between teachers and peasants reflected open and hidden social, political, and cultural differences. Peasants could hardly understand the efforts teachers were required to invest; they saw in them threatening representatives of external authorities-the Third Republic in France or the Jewish Colonization Association (JCA), the dominant philanthropic association in the Galilee. Main contestations concerned religion, which, for the teachers, became a symbol of all the negative aspects of peasant societies. Teachers also made great efforts to implant notions of romantic nationalism into societies to which such concepts were alien. Such attitudes were translated into thorny conflicts of influence between teachers and parents in rural communities. Consequently, teachers remained in practice socially semi-excluded.
\end{abstract}

\section{Keywords}

History of education;

France; Galilee settlements;

Teaching; Teachers. 


\section{Rural Environments and Transnational Features}

The year 1882 was significant in the history of education both in France, where compulsory education law was introduced, and in Hebrew Palestine, where the first Galilee moshava ${ }^{1}$, Rosh Pina, was founded, followed in the next two decades by 11 others, which through their schools became a significant cornerstone of Hebrew modern education. In both France and Palestine, 1882 began a massive and continuous process during which elementary education penetrated rural zones, reaching even the remotest and most peripheral villages, bearing on its wings the promises and the threats of modernity ${ }^{2}$. Teachers became the forebears of social and cultural changes, such as compulsory education for boys and girls or secular study programs, to the heart of conservative and God-fearing rural societies.

Rural education in France should be considered in the larger context of efforts undertaken by the Third Republic to "engineer" citizens through growing centralization of the educational system. The year 1879 saw the regulation of teachers' training, 1881 the abolition of tuition, and 1886 the banning of religious education from Republican schools. During the same period, education budgets tripled between 1878 and 1885. In

Palestine, still under Ottoman (and since 1918 British) rule, the Galilee moshavot were administered and economically managed by a powerful Jewish philanthropic society, the JCA, which saw in the educational system an efficient tool of regulation ${ }^{3}$. Without interfering in the contents of the study program (which consequently became totally dominated by the secularist spirit of the teachers), the JCA made noticeable efforts to make schools a central symbol of its cultural authoritarian control (Seltenreich, 2015, pp. 161-165).

This very rapid description already hints at the existence of some similarities. In both the French and Galilean arenas, teachers were pioneers of aggressive modernization, with schools as epicenters of struggle, while secularism stood as a main cultural theme of dissent. Were educational tensions in Galilee a result of transnational influences, a reflection of French Third Republic cultural phenomena, or were their apparent similarities rather incidental, which should mean that the attitudes of conservative rural environments to modernity developed independently?

\section{Methodological Approach}

In this paper, I use an archival study design to examine social phenomena and processes, described in various documents and sources, in a critical manner and through the lens of studies of transnationalism.

Studies of transnationalism focus on processes in which various cultural aspects within a given national sphere, such as social concepts, ideas, emotional reactions, or patterns of conduct, influence other national domains or, as was the case in rural France, local cultural spheres that were totally different from the dominant national one. This approach examines how such cultural influences may vary in their character,

\footnotetext{
${ }^{1}$ The mosahvot (singular: moshava) were rural settlements that symbolized the return of Jews to agriculture. "Hebrew" was a symbolic term that distinguished between the diaspora Jews and the regenerated type of Jew whom the renascent Hebrew society in Palestine aspired to create.

${ }^{2}$ For French education during the period, see Prost (1968), Weber (1976), and Mayeur (2004). For Hebrew education, see Dror (2007) and Seltenreich (2015).

${ }^{3}$ The JCA, the Jewish Colonization Association, administered the moshavot only since 1896, but they were administered previously by the French baron Edmond de Rothschild, who presided over the JCA and used practically the same administrative staff. For JCA, see Norman (1985) and Seltenreich (2008, pp. 35-51).
} 
their extent, or the durability of the cultural imprint they leave. The Froebel educational method, which laid the foundations of kindergarten education, was an illustrative example. Formulated in early-19th-century Germany, it regenerated again during the fin-de-siècle period in different places such as Finland, Crete, and the Galilee moshavot in Palestine. Unlike comparative historical methods, which concentrate on resemblances or dissimilarities, the emphasis in transnational studies is on the ways that processes of transfer operate and on how one cultural code becomes absorbed-partly or totally-into another (Mayer, forthcoming).

\subsection{Transnationalism in the context of the period of interest}

During the fin-de-siècle period, transnationalism was closely tied to the ideas of European cultural supremacy, which was not limited to colonial arenas. While cultural influences often became reciprocal in North and Western Europe, they rather bore a one-dimensional form in the Eastern and Southern European peripheries, not to speak of other continents. ${ }^{4}$ One-directional transnationalism was equally discernible through processes of shaping identities, when elements of dominant culture were intentionally adopted in order to create social distinction, as was the case of many Jewish intellectuals in interwar Europe. Franz Kafka's family in Prague or poet Paul Celan's family in Bucharest educated their children in German rather than the local Czech or Romanian idioms. Those last examples reflect voluntary acceptance of transnational influences, but this was not always the case, as the test cases hereafter examined will clearly illustrate. Indeed, cultural influences necessarily put into motion emotional reactions with potential lasting and irreversible consequences (Reddy, 2001).

While multiplying cultural contacts of the fin-de-siècle period became quite suitable for influences, education became a most effective instrument of transnationalism. Educational activities emphasized the reflection of transnationalism through channeled recontextualization of original concepts. For instance, the normative role of modernization was considered by teachers in rural France as a starting point for introducing a new civil republican order and consequently a dominant educational value. On the other hand, teachers in Galilee moshavot put forward another element of modernization, which was its potential for vital regeneration by shaping the New Hebrew type (Raichel, 1992). Yet, in both environments modernization was introduced through the influence of elementary school education. This dominant position of education was due to the combination of an ideal, the beneficial contribution of knowledge for the well-being of humanity, with a powerful means for its effective propagation through centrally conducted and controlled authoritative educational systems. In the early 20th century the idea that modernists could paternally dictate their concept of knowledge for the benefice of others was still shared by many. In many cases, transnationalism was translated by adapting universal knowledge to specific national values: republicanism in France and regeneration in Hebrew Palestine. Rural schoolteachers were in a particularly favorable position, being supported by powerful institutions, like the French ministry of education or the JCA in Galilee, while local populations, as this article will show, had hardly any possibility of resisting such influences and putting forward their alternative conservative interpretations.

\subsection{The nature of encounters between teachers and farmers}

The encounters between teachers and local rural populations in France and in Galilee, often tense and sometimes thorny, reveal many similarities. Most teachers in both arenas shared some basic patterns. In France rural teachers were homogeneous both in their social origin and in their formation. ${ }^{5}$

\footnotetext{
${ }^{4}$ This one-dimensional transnationalism is best reflected through two classical books: Said (1978) and Todorova (2009).

${ }^{5}$ The most thorough research on French teachers, with an emphasis on rural teachers, was led by Jacques and Mona Ozouf, who interviewed many fin-de-siècle teachers. Their research was summed up in Ozouf (1973) and Ozouf and Ozouf (1992).
} 
They came usually from either farmers' or lower-middle-class families, where the father was a minor official or himself a teacher. For those who came from farmers' families, becoming a teacher signified a passage from manual to intellectual occupation and In France rural teachers were homogeneous both in their social origin and in their formation. They came usually from either farmers' or lower-middle-class families, where the father was a minor official or himself a teacher. For those who came from farmers' families, becoming a teacher signified a passage from manual to intellectual occupation and hence an advance, both symbolic and economic, on the social ladder. Most teachers-to-be were selected through a concours and followed 3 years of studies in an école normale. During their formation they were subject to a strict study program and austere regulations. They left their écoles, monopolized by the Republic, absorbed with republican values and penetrated with a clear sense of reforming mission (Gaillard, 1996, pp. 28-30; Julia, 1994; Meyers, 1976; Nord, 1995; Prost, 1968; Regers, 2005, pp. 45-76). Most Hebrew teachers were born in little East European towns to well-off orthodox but relatively liberal families. Destined for commercial careers, many enjoyed home-schooling, rather exceptional in Jewish societies, and then were sent to non-Jewish gymnasiums in nearby towns where they became open to modernity and secularist culture and, at the same time, to Zionist ideas. They came to Palestine penetrated, like their French homologues, with a deep sense of romantic mission but, unlike them, with hardly any pedagogical formation (Dror, 1993; Seltenreich, 2015, pp. 175-190). Both French and Hebrew teachers were very young, about 20 years old, when they began teaching, and as young intellectuals (in their own eyes ... .) considered rural environments with certain haughtiness. ${ }^{6}$

Arriving in rural regions, teachers felt as they were borne on the wings of modernity (Gay, 2007, pp. 1-17) and thus became from many aspects somewhat alien to local traditions (Panelli, 2006). The French peasantry entertained a deep conservatism for hundreds of years: shut off from external urban cultural influences, suspicious of intellectual approaches which, in their eyes, represented the dangers of cunning. Conservatism ensured for them the persistence of the existing social order and consequently the ability to cope with the problems it could have created. ${ }^{7}$ The Hebrew peasantry, though it had existed for merely one or two generations, nevertheless imported the features of Jewish diaspora conservatism with great resemblance to the mentality that existed in rural France: extreme lack of openness and excessive caution. Unlike those who came in later waves of immigration, Galilee Hebrew farmers came with romantic attire to Zion but had neither a sentiment of national mission nor a vision of political ideology nor the courage to undertake any daring economic initiative (Ben-Artzi, 1997; Hadani, 1956).

The symbolic intellectual advantage of teachers, French and Hebrew alike, emphasized in various ways the cleavages between them and the farmers. The standard of change that teachers bore represented in their eyes both a vision and a mission. They thought about radical change, which should be directed at the very foundations of existing conceptions. They treated the reserved attitude of farmers with disdain rather than with any sensitivity or empathy. Teachers considered conservatism and modernity in the opposing terms of degeneration and regeneration-and, as such, as potentially leading to perdition or salvation (Presner, 2007). Those last two terms, though not employed, were constantly felt in the tense atmosphere that reigned between the two sides. They transmitted notions of dichotomist fatalities and therefore translated the cultural divergences into supposed religious terms.

${ }^{6}$ More detailed analysis of Hebrew teachers is found in Seltenreich (2014, pp. 87-177). Between the many biographies of teachers, see Karmi (1965) and Kostitzki (1988).

${ }^{7}$ On French rural mentality, see Chauvaud and Mayaud (2006). 
Moreover, the structural form of educational systems in the villages gave teachers many more opportunities to influence children and exert authority over them than their parents could have in practice. The committee of Menahemia in Galilee complained, for example, that the local teacher had a decisive influence on his pupils while their fathers were preoccupied all day long in the fields. ${ }^{8}$ Teachers had children at school under their spell each day for lengthy hours. They talked to them in a more sophisticated way than most parents did. Teachers mastered reading and writing, a privilege that not all parents shared. They enjoyed better symbolic social positions than the farmers. While farmers toiled with dirty and heavy clothes in the fields, exposed to sun or rain, teachers operated in their classrooms, clean and well-dressed. Decades later the most vivid memories people kept from Galilee teachers commemorated their handsomeness, warmth, and calmness. The teacher Jacob Klivanski, to give one of many examples, was remembered as a "smiling, quiet and orderly man, walking among us as if marching on soft carpets" (Michaeli, 1973, p. 170).

\subsection{The dynamics of encounters between teachers and farmers}

The main source of rural teachers' firm position is the constant backing they received from powerful external authorities: the republican institutions in France, and above all the ministry of education, and the JCA, combined since 1903 with the influential Hebrew Teachers Association (HTA) in Palestine ${ }^{9}$ Rural societies traditionally tended to avoid contact with institutional authorities, which were often represented by either taxation or jurisdictional agents. Both authorities, in France and in Galilee, which sought to propagate their values and establish social control through systematically established order, saw teachers as part of their agents of change and supervision. Education, in that way, became an element in a larger scope of acculturation of "primitive" populations ${ }^{10}$. Acculturation meant giving emotional priority to republican national views about liberty and equality, to JCA principles of thriftiness and industriousness, or to HTA values of nascent nationalism. Institutional dominance was reinforced by establishing the complete independence of rural teachers. Local farmers could neither hire nor discharge teachers nor influence their economic position nor dictate and control their educational activities. Such independence helped create paternalistic patterns of teachers' predominance, which was symbolically accentuated by the fact that teachers, at least in their first years, were 10 to 20 years younger than most farmers. Similar patterns of condescension toward rural populations existed in other environments, too-in late Tsarist Russia, for instance, where farmers depended so much on the regulations of provincial administrators that they felt uncomfortable on each occasion on which they happened to visit local urban centers (Worobec, 2002)

Another symbol of the social gap between teachers and farmers existed in the economic domain. Teachers could often earn less than some farmers, but while farmers' agricultural produce depended on weather irregularities, teachers enjoyed regular income, paid to them monthly by the French government or by a JCA representative in Galilee. This regularity was inconceivable for many rural minds: a French teacher met the village smith in the local bar: "Have you been on vacation today?"

\footnotetext{
${ }^{8}$ September 26, 1921, Central Zionist Archives (hereafter: CZA), S2 68513.

${ }^{9}$ The HTA indirectly affected the economic life of moshavot farmers, for instance through its control of school calendars and hence the availability of children as a labor force during agricultural high seasons.

${ }^{10}$ A good illustration is reflected in the disdainful manner with which Émile Meyerson, a JCA high official, treated local Galilee farmers. March 23, 1905, CZA, J15 6250/2.
} 
"Sure!” “And have you been paid?” “Indeed I have!” "But me, my friend, when I don’t work I don't get paid" (Ozouf, 1973, p. 150). Another teacher concluded: "The farmers envied all the functionaries who, it was believed, had simple and easy jobs but too highly rewarded" (Ozouf, 1973, p. 148). The same concepts reigned in the moshavot. When Yosef Vitkin, headmaster of a Galilee school, praised the romantic values of Hebrew agriculture, he was vehemently accused of false righteousness: "Have you ever been a whole day long in the field with only dry slice of bread for dinner? Have you returned home after a lengthy labor day only to find out there were not any tea or sugar?" (Zohari, 1971, p. 140). Galilee teachers were respected by the farmers, but no intimate terms existed between the two social groups because "they were learned people and were always nicely dressed" (interview with Shalom Attia, a retired school supervisor, Kiryat Ti'von, September 1, 1997). Galilee teachers, for their part, considered rural parents spitefully. They were deeply convinced that parents had "negative influences" on their children. One teacher even concluded that "parents should be given [by teachers] radical instructions about how to treat their children." 11

Yet the issues of the socially and economically privileged status of the teachers in both rural arenas, though they constantly nurtured emotional tensions, remained secondary to the deep cultural divergences concerning religion. In French or Galilee rural cultures, religion was translated not merely in terms of creed and cult but as the raison d'être for the cosmic order that defined and dominated nature, society, and the individual. Consequently, religious views became deeply entangled with conservative concepts. Both elements of creed and rudiments of social order were conceived in farmers' minds as constant in their nature and simple in their structure. They stood in the foundations of life-span routines and through their structural requirements supplied at the same time comprehensive order and peace of mind. Rural religiosity was basically unsophisticated, cultivated by deeply rooted apprehensions that bore semi-pagan features, reflected through endowing material symbols, like crosses or mezuzahs, with mystical significance or meticulously following routine weekly ceremonies in church or in synagogue. A French teacher, following the instructions of the inspecteur, removed a big wooden Jesus that was hanging in his classroom and hid it at his home. Immediately rumors circulated in the village that the teacher was going to set the wooden Jesus on fire. While he was absent from the village, two farmers broke into his house, and after a thorough and anxious search found Jesus in the attic. Although they were unable to see him in the dark attic, in feeling his feet they were reassured again (Ozouf, 1973, pp. 172-173). A Hebrew teacher was so furious at his pupils' habit of putting on their hats out of holy respect whenever they studied the bible in class that, one day, he circulated among them, removed by force all the hats, and disdainfully threw them into the schoolyard (Taplitzki, 1986, p. 30).

In the Third Republic, religion was seen as a major antithesis to republican values (as a republican anti-Christ, if I may borrow the term . . .). Many teachers, raised in a republican atmosphere, became radical secularists. They knew well that villages were Catholic bastions, alien cultural territory for them, but nevertheless many came there enthusiastically to fulfill what they considered their mission reformatrice. Yet their secularism reflected a clear religious vocabulary. One teacher confessed: "I was inspired by secularist creed." Another one explained that he "obeyed the inner God of my own conscience." A third one said: "I was anti-religious and felt it was my vocation to bring light to those naive and credulous people, to eradicate the anti-truth out of them" (Ozouf \& Ozouf, 1992, pp. 268-272).

${ }^{11}$ February 11, 1925. Teachers' meeting in Rosh Pina. Rosh Pina Archives, protocols file, no. 14. Seltenreich (2011, pp. 6-31). 
In Galilee moshavot teachers' secularist zeal was much the same, at times expressed with particular arrogance, according to farmers' complaints. During a journey of leading rabbis of Palestine in 1914 to Galilee, moshavot farmers vehemently protested about teachers who embarrassed young pupils by the manner in which they criticized their parents' beliefs (Horowitz, 1917/2001, pp. 130-132, 146, 148, 153). On another occasion, farmers complained that a local teacher drove his cart on Saturday, the day of sacred repose, "in public in front of the eyes of his appalled pupils at the very moment they left synagogue after prayer" (July 13, 1922, CZA, S2 702 267-268). But in practice most teachers' secularism, seemingly, was as shallow as the farmers' religiousness, leaning on emotionality and symbolism more than on a profound intellectual basis.

There were moments, though, in which teachers tended to mitigate religious tensions. Simha Vilkomitz, headmaster of Rosh Pina school in Galilee, who wanted to emphasize the cultural element in Judaism, gave lectures occasionally in the synagogue for farmers and pupils but took care to omit any religious references (Horowitz, 1917/2001, p. 140). In France, several secularist teachers married religiously in local churches, "in order not to offend our pupils," or else "forgot" to obey the instructions of the French ministry of education to abolish the custom of morning prayers within school buildings (Ozouf \& Ozouf, 1992, p. 220). Such compromising efforts existed in other places too, as testified by a Turkish teacher in rural Anatolia who, during the 1950s, partly yielded to heavy pressure by conservative parents first to locate the classes in the mosque building and later to disregard the secularist Turkish study program and secretly maintain some religious studies (Makal, 1978, pp. 190, 204).

The only power that could stand up to the teachers' secularist influence was a well-organized and resourceful religious authority, keen enough to contain the teachers' impact, capable of supplying the farmers with daily guidance and constant cultural leadership, an authority that could restore, at least partly, the faltered confidence of the farmers. Here a clear dissymmetry existed between the two arenas. In Galilee there were no rabbis in the moshavot and practically no authoritative religious persons in the whole region. The moshavot were in fact self-dependent for their basic religious needs, like ritual slaughter or appropriate fulfilling of prayer services. But they had no way to resolve any more complicated issues. The rabbis' journey of 1914, mentioned earlier, was a unique occurrence, although with a fading effect. In that way, religiosity was dominated by mechanical forms of ritual which were not backed by any scholarly or spiritual sources of inspiration.

In French villages, on the contrary, the church retained its powerful position. Administratively, each village was a Republican commune, with at least one residing teacher, which most often corresponded to the ecclesiastical paroisse, with a residing priest. Both school and church buildings symbolically dominated the village square. The Republic invested constant efforts to undermine the Church's position, which culminated in the separation in 1905 of church and state. Yet, as opposed to what happened in the moshavot, the constant and structured position of the Church in the villages contributed much to the emotional resilience of the farmers and to the proud preservation of a social and religious conservative spirit.

The proximity of teachers and priests in France could have become vulgar and even violent. Some priests named their dogs République (Ozouf \& Ozouf, 1992, p. 252). In certain villages, the priest burst into a classroom, threatening to confiscate by force from the pupils a history book prohibited by the Church. The teacher had to summon the mayor in order to drive the priest out of the school (Ozouf \& Ozouf, 1992, pp. 250251). But in many other cases, tensions between French teachers and priests were greatly subjected to necessary appearances and often represented symbolical opposing positions of Republic and Church more than true personal hostilities. On the day of his arrival, a teacher paid a visit to the priest village, who politely explained to him that "of course you have all my respect, but our common interest is not to maintain any social contacts in the future. If certain farmers see me talking to you regularly, they are even capable to ask higher 
ecclesiastical authorities to replace me." When a teacher had a newborn baby, the priest came to see him at night and proposed to baptize the child, an offer that the teacher respectfully declined because of the potential negative appearance (Ozouf, 1973, pp. 160, 167).

In Galilee, for lack of priests, there were no contestations between teachers and religious authorities apart from isolated events during the rabbis' journey. But things changed after 1914, when religious education made its entry into the moshavot, raising much animosity within the now divided teachers' community. The activity of the JCA, which strongly supported the modernizing tendencies of the teachers, was stopped by Ottoman authorities during World War I. The strong Jerusalem rabbinic leadership profited from the situation and finally succeeded in establishing traditional schools, hadarim, in some of the moshavot, which soon became unexpected competition for secularist schools. For the first time religious melameds, who could powerfully resist the teachers' influence, lived in the moshavot (Seltenreich, 2013). After the war some moshavot tried to maintain mixed schools, where secularist and religious teachers worked side by side. This situation provoked constant tensions with mutual acidic confrontations. ${ }^{12}$

Essentially, rural teachers of the early 20th century proved to be more emotional than intellectual. Conceptually, they understood modernity and religion in the superficial and simplistic terms of secularism and primitivism. One can say, in a paraphrase of Talal Asad, that they put forward the symbols of ideas rather than their essence. One French teacher explained that teachers did believe in God, but in their own manner. Unlike the priests, who took for themselves the exclusive right to interpret God's intentions, for teachers God remained a mystery (Ozouf, 1973, p. 254). That was not true. Teachers held fighting to eradicate primitive idioms like Yiddish in Palestine or provincial dialects in France (Hélias, 1975, pp. 209-212).

Many features of the sensitive encounters between rural modernizing teachers and local conservative populations were reflected in other countries too. Teachers in rural Finland during the 1950s, constantly told during their formation years that they were "builders of national civilization" and "flag bearers of noble ideals," were convinced, exactly like French and Hebrew teachers, that they were fulfilling a civilizing mission in the remote villages, obeying a "teacher's calling" and ready to face hardships. ${ }^{13}$ Though they did make efforts to take part in communal activities, they were still considered by the farmers with much reserve. The feeling was that they were more interested in what was happening "outside" than in the real concerns of local communities. At the same time, Finnish teachers were eager to place boundaries between their public and private roles and tended to befriend almost solely other colleagues. Such attitudes hardly contributed to their integration into communal intimacies (Anttila \& Väänänen, 2013, pp. 183-185). Finally, their excessive motivation for acculturation added another barrier between them and the farmers.

\section{Conclusion}

The existence of eventual transnational cultural influences reflect in fact the more profound issue of the effective impact of educational activity on rural conservative societies. Rural conservatism, as this article showed at length in France and in Galilee, as well as in Finland and Turkey, bore many similarities, essentially represented through the obstinate persistence of preconceived patterns, the dominant reliance on mystical and symbolical elements of religion rather than on its sophisticated sides, and the defiant rejection of new ideas, technologies, or opportunities.

\footnotetext{
${ }^{12}$ See, for example, the protocol of the farmers' meeting at Yavne'el, September 30, 1920, CZA, S2 684, 102-106.

${ }^{13}$ should be remarked that, unlike in France or Finland, Hebrew rural teachers were almost exclusively male. In all three test cases, local rural schools had a single teacher and, in any case, very rarely exceeded three (Anttila \& Väänänen, 2013, p. 193).
} 
Education, on the other hand, is much more structured, meant to introduce knowledge, values, and modes of thinking according to preconceived planning and through a pre-elaborated and controlled process, and consequently by its nature is more open to influences, transnational or other.

If any transnational influence did exist between the Third Republic and Galilee, it is necessary to identify an agent of cultural transfer. I believe this function was done by the philanthropic association, the JCA, that administered the moshavot. Unlike the Third Republic, the JCA was neither a national state nor a political regime, but it was forged in the atmosphere of Third Republic culture and in practice fulfilled the agency of a colonizing factor (Seltenreich, 2008, pp. 45-47). It adopted the French concept of the educational system as a vehicle for both propagation of knowledge through the introduction of appropriate values, mainly of loyalty and dedication, and centralized institutional control (Gaillard, 1996). The JCA gave teachers in the moshavot pedagogical autonomy as long as they helped introduce the JCA's leading values and ensure their absorption. Shared belief of teachers, French or Galilean alike, and the authorities in the benefices of modernism, combined with a deep sentiment of righteous cultural elitism toward primitive rural societies, guaranteed for the authorities the zeal of the teaching cadre. One may conclude that rural teachers in the Third Republic had more in common with their Galilee homologues than with their urban French colleagues.

Both groups of rural teachers became inculcated during their youth with the same cultural ideas of romantic nationalist regeneration. In France those were the years during which France tried to overcome the humiliating defeat of 1870, while in modern Palestine the dominant idea was of putting an end to two millennia of shameful diaspora life.

Teachers' attitude toward modernism was translated by the need to give a rationalized secularist order precedence over emotions. Emotions, mostly translated through the romantic exaltation of Galilee and French teachers, had to be a source of inspiration and energy but had no place in decision making. ${ }^{14}$ Teachers were conclusive in defining for their pupils the model types of "Hebrew" or "French" nation-builders as well as the model conceptions of "France" or "the Land of Israel." This combination of rational and emotional spheres equally translated the European concepts of masculinity which, in that way, became a source of transnational inspiration too. Modernism symbolically put the teachers (even lady teachers) in a "masculine" symbolic position against the effeminate farmer (Seltenreich, 2011).

Transnational influences in rural French and Galilee environments seem to be, in conclusion, limited mainly to the dominant paternal modernism introduced by the teachers and much less, if at all, to the passive conservative farmer populations.

${ }^{14}$ Teachers' attitudes, as reflected in many French or Hebrew testimonies, clearly reflect the existence of emotional communities, a concept thoroughly defined and described by Rosenwein

(2002, pp. 821-845; 2007, pp. 1-31). 


\section{References}

Anttila, E., \& Väänänen, A. (2013). Rural schoolteachers and the pressures of community life: Local and cosmopolitan coping strategies in mid-twentieth-century Finland. History of Education, 42(2), 182-203. https://doi.org/10.1080/0046760X.2013.766267

Ben-Artzi, Y. (1997). Early Jewish settlement patterns in Palestine, 1882-1914. Jerusalem: Magnes Press.

Central Zionist Archives. Jerusalem.

Chauvaud, F., \& Mayaud, J.-L. (Eds.). (2006). Les violences rurales au quotidien. Paris, France: La Boutique de l'Histoire.

Dror, Y. (1993). The new rural school in Upper Galilee (Eretz, Israel) at the beginning of the twentieth century. Journal of Research in Rural Education, 9(3), 179-190.

Dror, Y. (2007). "National education” through mutually supportive devices: A case study of Zionist education. New York, NY: Peter Lang.

Gaillard, J.-M. (1996). Éduquer et instruire. L’Histoire, 202, 28-30.

Gay, P. (2007). The lure of heresy: Modernism. New York, NY: Norton.

Hadani, A. E. (1956). Settlement in Lower Galilee: A fifty years saga. Ramat Gan, Israel: Massada [Hebrew].

Hélias, P. J. (1975). Le cheval d’orgueil. Paris, France: Plon.

Horowitz, J. (1917/2001). The journey. Nethania, Israel: Zimrat Ha'aretz [Hebrew].

Julia, D. (1994). Le choix des professeurs en France: Vocation ou concours?

Paedagogica Historica, 30, 173-205.

Karmi, Z. (1965). An educator and his way. Haifa, Israel: Haifa Municipality [Hebrew].

Kostitzki, A. (1988). Before dawn: Tales of pioneers in Galilee. Tel Aviv, Israel: Israeli Ministry of Defense [Hebrew].

Makal, M. (1978). Un village anatolien. Paris, France: Plon.

Mayer, C. (forthcoming). Transnational and transcultural perspectives: Approaches to studying the circulation and transfer of educational knowledge. In E. Róldan Vera \& E. Fuchs (Eds.), The concept of the "transnational": Approaches-research areas-challenges. London, UK: Palgrave Macmillan.

Mayeur, F. (2004). Histoire générale de l'enseignement et de l'éducation en France: Vol. 3. De la Révolution à l'école républicaine, 1789-1930. Paris, France: Perrin.

Meyers, P. V. (1976). Professionalization and societal change: Rural teachers in nineteenth-century France. Journal of Social History, 9(4), 542-558.

Michaeli, B.-Z. (1973). Sedjera, its history and personalities: Seventy-fifth jubilee, 1899-1973.

Tel Aviv, Israel: Am Oved [Hebrew].

Nord, P. (1995). The republican moment: Struggles for democracy in nineteenth-century France. Cambridge, MA: Harvard University Press.

Norman, T. (1985). An outstretched arm: A history of the Jewish Colonization Association. London, UK: Routledge and Kegan Paul.

Ozouf, J. (1973). Nous, les maîtres d'école: Autobiographies d’instituteurs de la Belle Époque.

Paris, France: Gallimard. 
Ozouf, J., \& Ozouf, M. (1992). La République des Instituteurs. Paris, France: Gallimard / Le Seuil.

Panelli, R. (2006). Rural society. In P. Cloke, T. Marsden, \& P. Mooney (Eds.), Handbook of rural studies (pp. 63-90). London, UK: Sage Publications.

Presner, T. S. (2007). Muscular Judaism: The Jewish body and the politics of regeneration.

New York, NY: Routledge.

Prost, A. (1968). L’enseignement en France, 1800-1967. Paris, France: Armand Colin.

Raichel, N. (1992). Jewish teachers' faith in their ability to mold a "New Jew" as the central motive in early Jewish education in Palestine (1882-1914). Dor Ledor, 19, 29-50 [Hebrew].

Reddy, W. M. (2001). The navigation of feeling: A framework for the history of emotions. Cambridge, MA: Cambridge University Press.

Regers, R. (2005). From the salon to the schoolroom: Educating bourgeois girls in nineteenth-century France. University Park, PA: Pennsylvania State University Press.

Rosenwein, B. (2002). Worrying about emotions in history. American Historical Review, 107 (3), 821-845. https://doi.org/10.1086/ahr/107.3.821

Rosenwein, B. (2007). Emotional communities in the early Middle Ages. Ithaca, NY, and London, UK: Cornell University Press.

Rosh Pina Archives, protocols file, no. 14.

Said, E. W. (1978). Orientalism. New York, NY: Vintage Books.

Seltenreich, Y. (2008). Cultural aspects of philanthropy: Belle Époque administrators and Jewish peasants in the Galilee. Mediterranean Historical Review, 23(1), 35-51. https://doi.org/10.1080/09518960802127465

Seltenreich, Y. (2011). Masculine representation of farmers in Galilee moshavot, 1882-1939. Social Issues in Israel, 12, 6-31.

Seltenreich, Y. (2013). The heder in the Galilee moshava: The farmer's stronghold against modernism. Dor Ledor, 44, 326-350 [Hebrew].

Seltenreich, Y. (2014). People from here: Education and educators in Galilee moshavot during the Yishuv period, 1882-1939. Jerusalem and Ramat Gan, Israel: Yad Ben Zvi and Bar Ilan University Press [Hebrew].

Seltenreich, Y. (2015). Secularism, education, and emotions: Cultural tensions in Hebrew Palestine (1882-1926). New York, NY: Peter Lang.

Taplitzki, Z. (1986). Youth in Sedjera. Tel Aviv, Israel: Traklin [Hebrew].

Todorova, M. (2009). Imagining the Balkans. Oxford, UK: Oxford University Press.

Weber, E. (1976). Peasants into Frenchmen: The modernization of rural France. Stanford, CA: Stanford University Press.

Worobec, C. D. (2002). Masculinity in late Imperial Russian peasant society. In B. E. Clemens, R. Friedman, \& D. Healy (Eds.), Russian masculinities in history and culture (pp. 76-93). New York, NY: Palgrave.

Zohari, H. (1971). Life diary: Memories. Jerusalem: Academon [Hebrew]. 